\title{
Manuscript Collections: The William Lloyd Harding Papers in the Sioux City Public Museum
}

\author{
SCott Sorensen \\ JoHN LEDouX
}

The Sioux City Public Museum is located at 2901 Jackson Street in Sioux City, housed in an 1890s mansion built by John Peirce, an early Sioux City real estate dealer and city promoter. In December 1978, the Peirce House was entered on the National Register of Historic Places. The archival area is on the third floor and is open to the public Monday through Friday from 9 a.m. to 5 p.m. The museum is closed on national holidays.

Through a grant from the National Historical Publications and Records Commission, the Sioux City Public Museum is arranging, organizing, and preparing finding aids for some of its major archival collections. Work began on this two-year project on November 1, 1979. The new organization will greatly facilitate use of the archival materials.

The Sioux City Public Museum has a wealth of books, documents, and other materials relating to the history of the Sioux City region. There are also several manuscript collections of state-wide and national importance. The personal papers of former Iowa governor William Lloyd Harding form one of the largest and most interesting collections at this museum.

W. L. Harding was born on a farm near Sibley, Iowa on October 3, 1877 and attended country schools in that vicinity. 
He came to Sioux City in 1897 to enroll at Morningside College. Harding soon drew local notice for his oratorical abilities both in debate and in political circles. He later attended the University of South Dakota and received his law degree in 1905.

Harding entered Republican party politics and advanced quickly. He was elected to the Iowa House of Representatives in 1906 and served Woodbury County in that capacity from 1907 to 1913. During these years, Harding garnered a state-wide reputation. He sought the office of Iowa lieutenant governor in 1912 during an election that was highly divisive for the alreadysplintered Iowa Republican party. Harding won by a small majority and served under Governor George W. Clarke for two terms (1913-1917).

Prohibition was a major issue during the Clarke/Harding tenure. Iowa periodically had been a "dry" state, but enforcement never had been very thorough, especially in river communities like Sioux City. During the early 1910s, the state allowed liquor sales under the mulct law, a system deemed unworkable by many. The Iowa General Assembly banned liquor sales completely in 1916 .

Harding announced his candidacy for the governorship of Iowa in 1916. Three other Republican candidates, ranging from a Stand-pat to a Progressive, made the party primary battle highly competitive. Harding received a large plurality of the votes and emerged with the Republican nomination to face Democratic publisher Edwin T. Meredith in the general election. The heated primary campaign, however, had created a chasm between Harding and other party leaders and newspaper editors.

The fall campaign between Harding and Meredith was one of the fiercest in Iowa's history. Several controversial issues helped to foster this stormy climate; debates continued on prohibition and the quality of roads needed in Iowa. Vigorous editorials written by both sides heightened the tension tremendously. Although Republicans generally were stronger supporters of prohibition, Harding's opponents correctly labeled him a "wet." Many religious leaders, including both the president of Morningside College and the pastor of Harding's church, denounced Harding's candidacy and supported Meredith. Harding also 


\section{The Annals of Iowa}

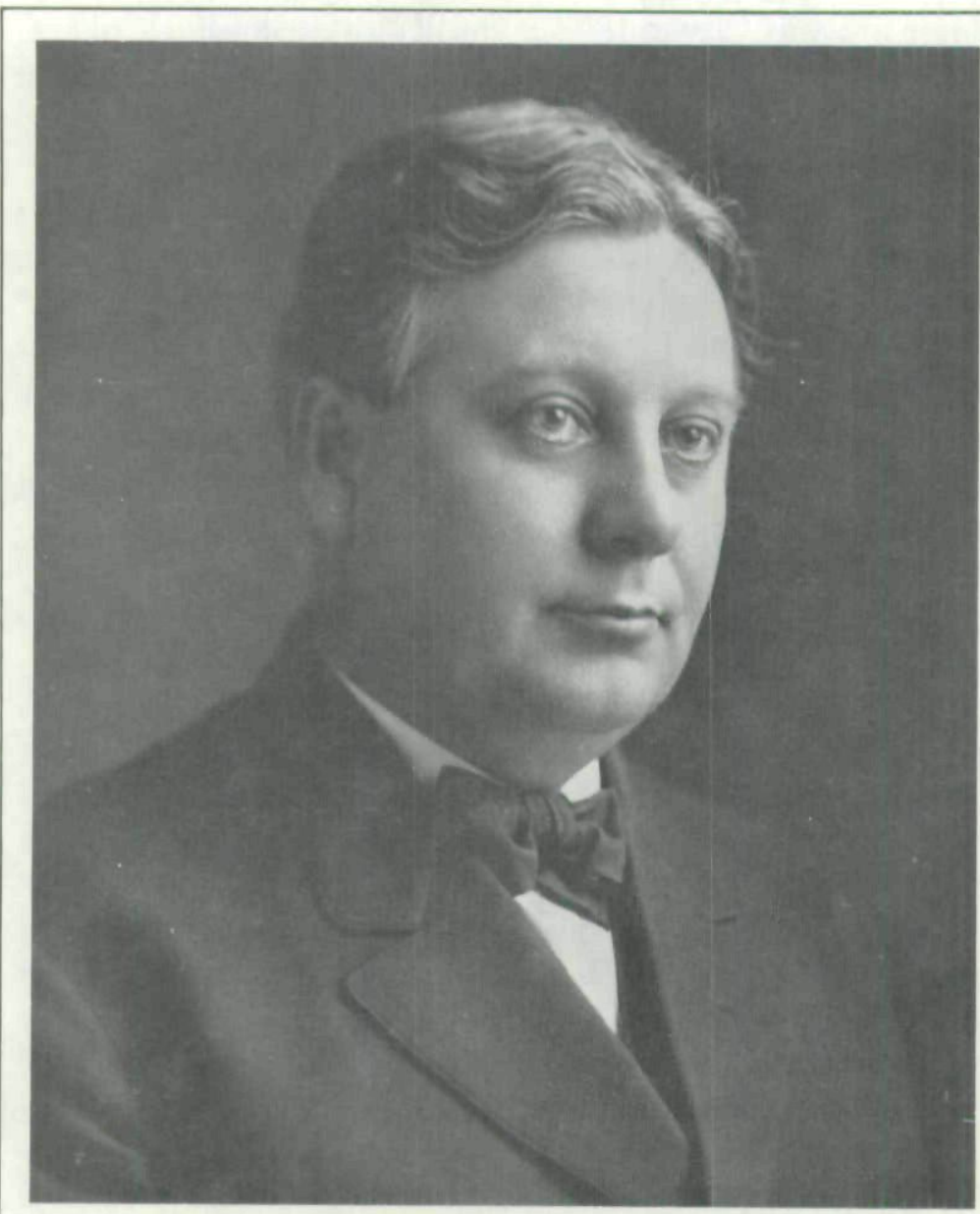

Governor William L. Harding, ca. 1920.

received criticism from road-improvement advocates because he questioned the cost/benefit ratio of such a program.

Despite the volatile campaign and a Democratic slate headed by an incumbent president, Harding swept to victory with a clear and decisive margin, receiving nearly seventy percent of the vote. He ran ahead of the remaining state Republican ticket and considered the result a mandate and a repudiation of his newspaper opponents, especially the Des Moines Register and Leader. Only months after Harding was inaugurated as Iowa's 
twenty-second governor, the United States entered World War I. The duties and responsibilities of guiding the state during war were the primary concerns of Harding's first term. The governor and his staff worked diligently and successfully to raise Iowa's quota of money and men when each call was issued. Harding's zeal in managing the home front led to a major political blunder. In May 1918 he issued his infamous Language Proclamation outlawing the use of any foreign language in public, in schools, in churches, or on telephones. Most residents approved a ban on the German language, but disallowing the use of all foreign languages angered Iowa citizens of foreign birth.

Harding stood for re-election in 1918. His opponent was Claude R. Porter, a United States district attorney who had twice before been defeated in attempts to become Iowa's governor. Porter campaigned against Harding's war record, and especially against the governor's Language Proclamation. Without a doubt, Harding's ban on foreign languages hindered his bid for re-election. Although he defeated Porter by approximately ten thousand votes, he suffered a severe decrease in popularity from 1916. Indeed, in this election Harding ran behind the rest of the Republican ticket.

World War I ended only days after the 1918 election. Harding's second term, therefore, revolved around shifting Iowa's economy to a peace-time footing. He had much more time to devote to the internal affairs of the state. Improvements of roads and parks and state tax reforms were high on Harding's list of priorities.

A controversy over Governor Harding's alleged misuse of the governor's pardoning power disrupted his plans, however. On November 16, 1918 Harding pardoned one Ernest Rathbun, a convicted rapist, before Rathbun had served one day of his life sentence. Disclosure of the pardon produced immediate adverse reaction and it was a major news story for months. The Des Moines Register and Leader and other newspaper opponents immediately condemned the governor's action and questioned the motivation, hinting at bribery. Finally, the Iowa House of Representatives investigated the matter. At one point, impeachment proceedings were instigated against Harding, the only 
time an Iowa governor has been subjected to such a move. These proceedings were halted the next day, but Governor Harding's political career was ended.

Harding retired from office in January 1921 and entered the insurance business in Des Moines. He still had a powerful speaking voice, however, and soon embarked on the Chautauqua circuit. He became a leading exponent for the creation of the St. Lawrence Seaway and campaigned for national Republican candidates. Significantly, most of his talks were given outside of Iowa. Harding died in December 1934 at the age of fiftyseven.

The Sioux City Public Museum received the papers of the Governor William L. Harding Collection in the late 1960s. His wife, Carrie Lamoreux Harding, compiled most of the collection over a span of many years. The collection is stored in eleven acid-free document boxes and nine acid-free record storage boxes; it is approximately twenty linear feet in size.

The Harding collection covers the years 1830 to 1964 . It is organized by document classification. The manuscripts within each classification section are dated chronologically. The collection also includes personal papers of the Harding and Lamoreux families.

The first section of the Harding collection contains biographical information on the governor and his family. The next section consists of Harding's political and professional correspondence during the years 1905 to 1934 , from his first campaign for the Iowa House of Representatives to his last national speaking engagements. The majority of this professional correspondence covers the years 1916 to 1934 and concerns his gubernatorial campaigns, the prohibition issue, state Republican and Democratic party politics, national politics, raising troops for World War I, Harding's home front war policies including his 1918 foreign language ban, the Rathbun affair from the initial pardon to the aftermath of the impeachment proceedings, and Harding's later speaking engagements.

The third section is composed of personal correspondence of the Harding family (1906-1934). Other sections include: official documents such as certificates, awards, and proclamations; texts of speeches and addresses delivered by Harding (1908- 
1934); campaign literature and miscellaneous political documents (1912-1930); documents concerning the 1918 Rathbun pardon case; memorials to Governor Harding (1934-1937); and assorted newspaper clippings and pamphlets. There are also hundreds of photographs of the Harding family, arranged chronologically (c. 1870-1964).

Among the bound volumes in the Harding collection are Carrie Harding's diaries (1907, 1915, 1934, 1963-1965), registry books from the Hardings' wedding (1907), twenty photograph albums of the Harding and Lamoreux families (c. 1870-1963), and assorted other books belonging to Mrs. Harding.

The final section consists of twenty-nine scrapbooks containing thousands of newspaper clippings, mostly about Governor Harding. These scrapbooks, compiled by Mrs. Harding, provide perhaps the most complete account of every facet of Harding's career and Iowa politics available in this collection. Mrs. Harding carefully included reports both favorable and unfavorable to Governor Harding. Topics covered in the scrapbooks are: Harding's early political years, legislative programs he supported, his campaigns for governor, the prohibition issue, Harding's duties as war governor, the foreign language ban, Harding's speaking engagements, and Iowa politics in general.

Some prominent authors of correspondence in the William Lloyd Harding Collecton are:

Coolidge, Calvin

Cowles, Gardner

Dolliver, Jonathan Prentiss

Hammill, John

Harding, Barbara Esther

Harding, Carrie L. (Mrs. W. L.)

Harding, William Lloyd
Herring, Clyde

Hoover, Herbert

Hughes, Charles Evans

Lowden, Frank

Perkins, George D.

Taft, William Howard

Wilson, Woodrow

William L. Harding was certainly one of Iowa's most controversial governors, and the Harding Collection at the Sioux City Public Museum provides the researcher with a good overall source of information about this public figure. The collection will also be useful to any student of early twentieth-century Iowa political history. 
Copyright of Annals of Iowa is the property of State of Iowa, by \& through the State Historical Society of Iowa and its content may not be copied or emailed to multiple sites or posted to a listserv without the copyright holder's express written permission. However, users may print, download, or email articles for individual use. 